\title{
圧力振動場に設置された単一固定微小気泡周りの 非定常・非ニュートン有限要素解析*
}

\author{
岩田修一*1, 高島徹*2, 大石明香*2 \\ 山田悠介*2, 森秀樹*2

\section{Unsteadystate Finite Element Analysis of Non-Newtonian Fluid around a Fixed Small Bubble under Pressure ${ }^{-}$Oscillating Field}

\author{
Shuichi IWATA*3, Toru TAKASHIMA, Sayaka OISHI, \\ Yusuke YAMADA and Hideki MORI \\ ${ }^{* 3}$ Department of Material Engineering, Nagoya Institute of Technology, \\ Gokiso-cho, Showa-ku, Nagoya-shi, Aichi, 466-8555 Japan
}

\begin{abstract}
A finite element analysis of unsteadystate local flow of Carreau-Yasuda model fluid around a small air bubble is presented. The bubble radius is imposed to change sinusoidally determined by the frequency of pressure-oscillation, maximum and minimum diameter of the air bubble observed from experimental video data. The simulation results are compared with the experimental results consist of local velocity and shear rate profiles under pressure-oscillating field measured by PTV technique. It was found that apparent viscosity of the very thin film region around the bubble is lowered due to higher shear rate. The shear rate profiles in the upper and side region of the air bubble obtained by the PTV technique are good agreement with the simulation results. In addition, the shear rate at the bubble surface agreed well with the estimated shear rate obtained with the simple sphere model.
\end{abstract}

Key Words: Non-Newtonian Fluid, Pressure--Oscillating, Finite Element Method, Bubble, Axisymmetric Flow, Particle Tracking Velocimetry

\section{1. 腥言}

高粘性流体に混入した気泡を除去することはそのの 粘性のため容易ではない.この問題に対し, 筆者らは, 新たに圧力振動脱泡法 (Pressure-Oscillating Defoaming: POD）を開発しており，単一気泡を対象に奏験的な検 討をおこなった(1)(2).図1注実験装置の概要図である. 図中左は全体図であり, 右は容器部分の拡大図である. 試料溶液で充たされたセルには, 所定の体積量の気泡 が 1 個設置されており，セル下部のゴム製薄膜に低周 波振動が与えられる. パスカルの原理より，薄膜への 外力に応じセル内圧力は変化する. 仮に, 低周波信号 を与えると，意図的にセル内の気泡を，繰返し収縮・ 膨張させることが可能となる．その際，気泡近㥬には 局所剪断場が継続的に形成される. Shear-thinning 性流 体の場合，気泡近傍における粘度の減少から，気泡上 昇速度の増加が期待される.

岩田らは, Shear-thinning 性を示すポリアクリル酸ナ

* 原稿受付 2008 年9月18日.

*1 正貣, 名古屋工業大学大学院工学研究科物質工学票攻 (函466-8555 名古星市昭和区御器所町) .

*2 名古屋工業大学大学院工学研究科物質工学專攻

E-mail : iwa@nitech.ac.jp
トリウム水溶液(SPA aq.) と, ニュートン粘性を示す水 飴水溶液を用い，それぞれ単一気泡の自然上昇時にお ける気泡上昇速度と, 圧力振動場における気泡上昇速 度とを実験的に比較 ${ }^{(1)(2)}$ したところ，SPA aq.では，圧 力振動により顕著に気泡上昇速度が加速されることが 観察された。

そこで，気泡近傍での局所流れを推算するため，上 昇する気泡をビデオ撮影し，気泡径の時系列データを 求め, 真球気泡周りの球対称流れの仮定により気泡表 面における液側の剪断速度を評価した。 その結果, 気 泡表面の剪断速度は，試料流体の剪断粘度が著しく低 下する領域に達しており，剪断粘度の低下が気泡上昇 速度の促進に大きな役割を果たしたことが示された(2).

しかしながら，この段階では，溶液の剪断粘度特性 以外にも，例えば強い循環流が系内に存在するなど， まったく異なるメカニズムにより気泡上昇が促進され るという可能性を否定することはできない，そこで， 系内の対流と気泡近傍の局所流れに注目し，顔料系卜 レーサーを用いたセル全体の流れの可視化実験が行わ れ，系内には気泡移動を促進するような大きな対流は 確認されなかった。 また, 可視化情報から得られた気 


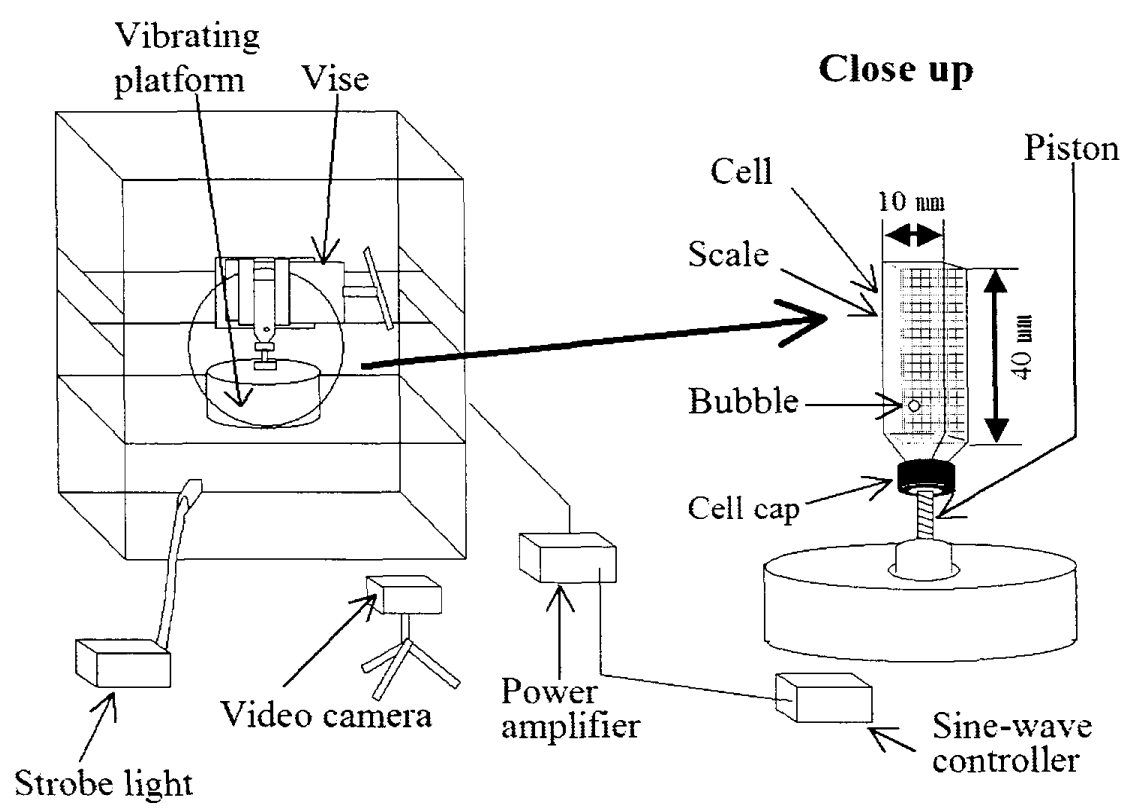

Fig.1 Experimental apparatus of the POD system

泡近傍の様子から, 圧力振動によって生じた気泡近傍 の剪断が，気泡上昇を促進する主な理由であることが わかった(3).

これまで, 圧力振動場での気泡上昇速度の促進評価 は，すべて実験的な検討が中心であった。 そのため, 異なる物性を示寸溶液や，気泡径や周波数などが異な る条件において効果が得られるかどうかを判断するに は，その都度実験を行う必要があり，流動解析による 気泡上昇速度の推算方法の確立が望まれる。

静止流体中を上昇する気泡についての解析に注目 すると，周期的にノズルから放出される気泡周りの流 れ解析( ${ }^{(4)}$ や Power-Law 流体中の気泡上昇の解析 ${ }^{(5)}$, 粘 弾性流体中を上昇する気泡形状とその近傍流れに関す

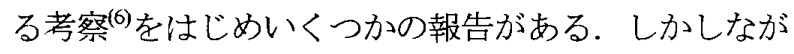
ら, 非ニュートン流体中を周期的に膨張・収縮を繰り 返す気泡周りの流動解析例は報告されていない．

そこで今回, PTV 法による気泡近傍流れの測定実験 とほぼ同じ条件において，気泡中心が固定された膨 張・収縮寸る単一真球気泡周りの非定常非ニュートン 有限要素解析を行い, 両者を比較検討した.

\section{2. 気泡の表面における罚断速度評価}

圧力振動に用いる周波数は $300 \mathrm{~Hz}$ であり, 市販のビ デオカメラを用いただけでは気泡径の時系列変化を計 測することはできない. また，超高速度力メラでは， 入手は困難であり，長時間撮影も難しい，そこで，岩 田らは，気泡上昇速度が比較的遅く，極めて周期的な 流れが支配的であることに注目し，压力振動周波数と わずかに異なる周波数で発光するストロボを用い，気 泡径の時系列変化を計測した ${ }^{(1)(2)}$. このデータを用い,
球対称流れを仮定のもと, 図 2 に示す微小体積 $\Delta V_{0}$ の 変形加ら, 気液界面における液側の剪断速度の評価を 試みた。この方法では，ビデオ画像で得られた気泡径 の時系列データのみが必要である. 以降,この方法を， 真球モデルと呼ぶこととする.

また，気泡近傍の流れを直接的に計測するには，気 泡近傍に現象に影響を及ぼさないトレーサーを多数配 置し，単位時間でのそれら粒子の移動距離から速度分 布を評価する PTV 法がある.今回, 真球モデルと, PTV モデルによる評価方法を簡潔に示す.

\section{$2 \cdot 1$ 真球モデル 真球モデルに適用される仮} 定は, 次の通りである.

- 球対称流れ.

・振動時に気泡中心は移動しない.

・静止時の半径 $r_{0}$ の気泡が, 振幅 $A$ と角速度 $\omega$ によ り気泡径 $r か ゙$ 次式の如く変化する.

なお，真球モデルと後述のPTV モデルについては，球 座標系で表記されることに注意されたい.

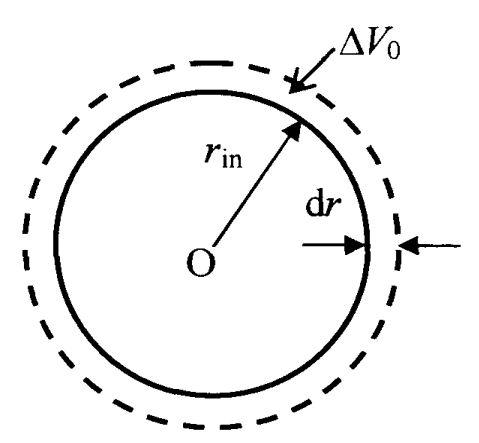

Fig.2 A controlled volume of thin shell around an air bubble 


$$
r=r_{0}+A \sin \omega t
$$

式(1)より, 気泡表面速度は,

$$
u=d r / d t=A \omega \cos \omega t
$$

で与えられる. 球対称流れであり，仰角ならびに方位 角方向の速度が無く，一様であることを考慮すると， 剪断速度は，次式の如く得られる。

$$
\dot{\gamma}=\sqrt{2 S: S}=\sqrt{2 u_{r}^{2}+4 \frac{u^{2}}{r^{2}}}
$$

ここに, $\boldsymbol{S}$ は変形速度テンソルであり，次式で定義さ れる。

$$
\boldsymbol{S}=\left(\nabla \boldsymbol{v}+\nabla \boldsymbol{v}^{\mathrm{T}}\right) / 2
$$

図 2 に示す半径 $r_{\text {in }}$ の気泡を取囲む微小体積の液体 $\Delta V_{0}$ に注目すると, 気泡の膨張収縮に伴い形状が変化 することに着目し, 時刻 $t$ と $t+\Delta \boldsymbol{~}$ の気泡半径から, 式 (3)中の $u$ の微分值 $u_{r}(\equiv \partial u / \partial r)$ は，近似的に次式に より求められる(1).

$$
u_{r}=\frac{1}{\Delta t}\left[\left(\frac{\left.r_{i n}\right|_{t}}{\left.r_{i n}\right|_{t+\Delta t}}\right)^{2}-1\right]
$$

2 -2 PTV モデル 図 1 の実験装置の構造に注 目すると，セルは，下部から加圧される. 物質収支を 考慮すると，図3のように，実線で示される真球形状

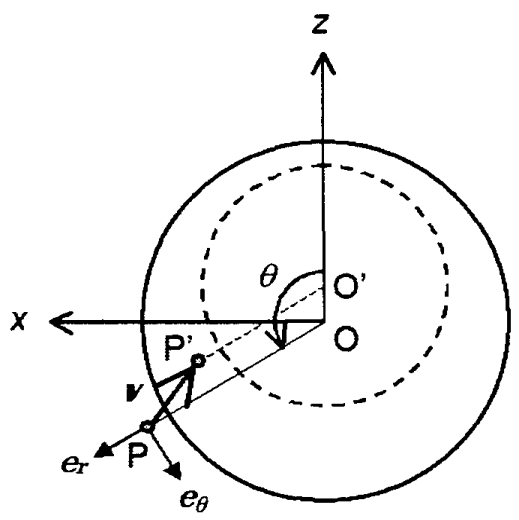

Fig.3 Cross sectional view of an oscillating bubble in $x-z(\phi=0)$ plane

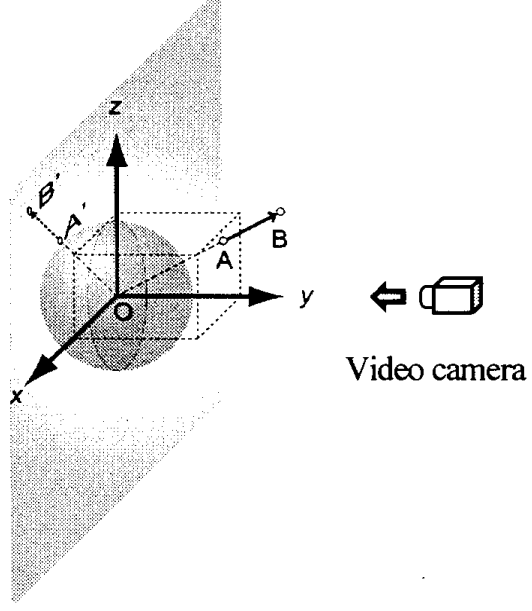

Fig.4 Geometrical description of particle path from A' to B' recorded by a video camera when moving particle from $A$ to $B$ near a bubble surface

の気泡は，收縮時には中心位置は $z$ 軸方向にO から O’ 一移動し, 気泡近傍のトレーサーはP から P'へ移動す る. 膨張時にはその逆の挙動を示すことが考えられる. この場合, 気泡近傍の流体には, 球対称流れの仮定が 厳密には成立しない，このような系における気泡表面 での剪断速度評価を行う。

図 3 は, 膨張時の気泡中心を原点と置き, $-y$ 軸方向 に原点を見た図である.球座標系における $\phi=0$ 面，す なわち $x-z$ 平面上の速度分布を求める. まず，膨張時 と収縮時のビデオ画像をPC画像データとして取込み, 気泡近傍に散在する各トレーサ一粒子について， $x$ 方 向と $z$ 方向の移動距離からそれぞれ移動速度ベクトル $v$ を求めた．速度ベクトル $v$ と，単位ベクトル $e_{r}, e_{\theta}$ との内積からそれぞれ半径方向速度 $u$ と周方向速度 $v$ を求めた. 速度 $w$ と $\phi$ 方向に一様な軸対称流れを考慮 寸ると，剪断速度は次式のように求められる.

$$
\begin{aligned}
& \dot{\gamma}=\sqrt{2 \boldsymbol{S}: \boldsymbol{S}}=\left\{2 u_{r}^{2}+r^{2}\left(\frac{v_{r}}{r}+\frac{u_{\theta}-v}{r^{2}}\right)^{2}+2 r^{4}\left(\frac{u+v_{\theta}}{r^{3}}\right)^{2}\right. \\
& \left.+2 r^{4} \sin ^{4} \theta\left(\frac{u \sin \theta+v \cos \theta}{r^{3} \sin ^{3} \theta}\right)^{2}\right\}^{\frac{1}{2}}
\end{aligned}
$$

図 4 は，y軸方向にビデオを設置し気泡を撮影する 様子を模式的に示したものである. ビデオは 2 次元的 な情報を記録するため，気泡は，最も気泡径が大きく なる $x-z$ 平面上の気泡形状が記録される．また，気泡 近傍に設置されたトレーサーは，常に， $x-z$ 平面上に存 在するとは限らない，例えば，トレーサー粒子 A が B に移動する場合，ビデオ画像には A'から B'への移動 


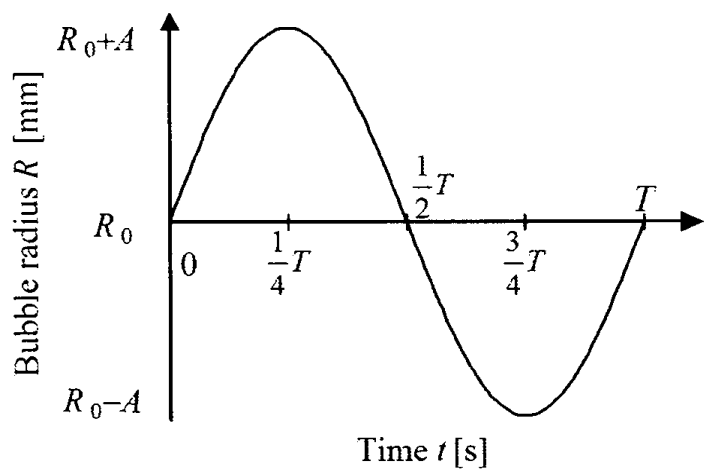

Fig.5 Change in bubble radius over a cycle

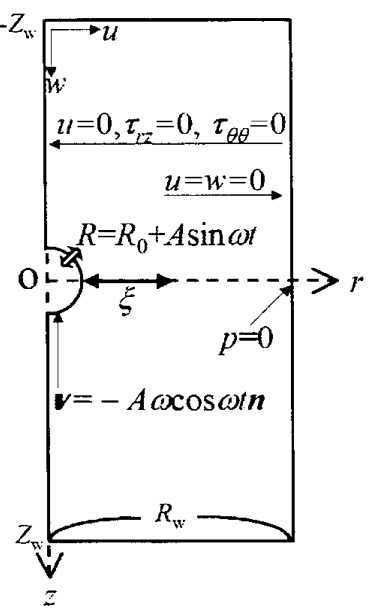

Fig.6 Boundary conditions and coordinates

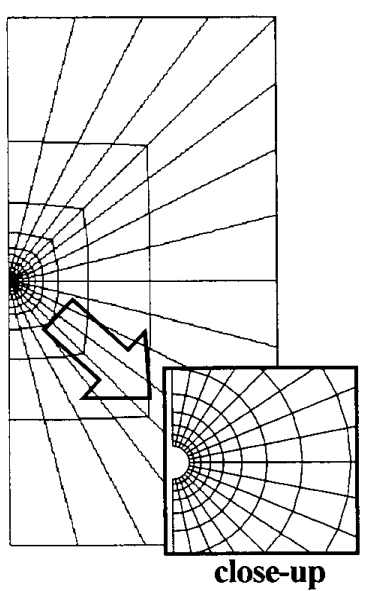

Fig.7 FEM meshes and close-up view around a bubble
として記録されるため, $x-z$ 平面上に存在するトレーサ 一が最も速度が大きい，岩田らは，気泡表面からの距 離ごとにトレーサーの半径方向速度と周方向速度を角 度 $\theta$ で整理した(3). 各 $\theta$ における速度の最大值に注目す ると，滑らかな分布を呈することがわかった.このこ とを考慮し，それぞれの速度の決定には，ビデオ画像 上で気泡表面から所定の距離だけ離れたトレーサーの 速度データをそれぞれ集めた後，近隣のトレーサー速 度を比較し，その中で最も大きく移動したトレーサー をその角度 $\theta$ における移動速度として用いた。

\section{3. 計算方法と境界条件}

気泡の膨張・収縮をともなう単一気泡周りの等温・ 非定常・非王縮性の軸対称の液流れ問題を, Galerkin 有限要素法により離散化し，速度・圧力を反復解法に より求めた，解析には，次の仮定を用いた，気泡半径 $R$ は，図 5 の様に周期的に変化し，式(7)の如く与えら れる. 気泡の中心位置は，原点 $\mathrm{O}$ に固定されると仮定 する. したがって，気泡表面上の速度は式(2)と同様に 求められる. 球の膨張・収縮にともなう体積変化を補 償するため，原点から計算領域の上端・下端までの距 離 $Z_{w}$ を式(8)の様に与えた. ここに， $\Delta H$ は気泡の半分 相当の体積変化を, 半径 $R_{\mathrm{w}}$ の円筒状の計算領域の断面 積で割った值であり，式(9)の様に与えられる．外側円 筒壁面の速度は $\boldsymbol{v}=0$ であり，その $z=0$ 上に圧力 $p=0$ を与える.また重力を無視する。

$$
\begin{aligned}
& R=R_{0}+A \sin \omega t \\
& Z_{w}= \pm\left(Z_{w 0}+\Delta H\right)
\end{aligned}
$$

$$
\Delta H=\left[6 R_{0}^{2} A \sin \omega t+6 R_{0}(A \sin \omega t)^{2}+2(A \sin \omega t)^{3}\right] / 3 R_{w}{ }^{2}
$$

ここに, $R$ は時刻 $t$ における気泡半径, $R_{0}$ は平均気泡 半径, $A$ は振幅, $\omega$ は角速度 $(\omega=2 \pi f), f$ は振動数である. 本解析では, PTV 実験 ${ }^{(3)} の$ 条件に合わせ, $R_{0}=0.676 \mathrm{~mm}$, $A=0.0705 \mathrm{~mm}, f=300 \mathrm{~Hz}$ を用いた。本解析に適用され る境界条件を図 6 にまとめた。

図 7 は，要素分割図 $(20 \times 16$ mesh $)$ であり，図中右下 は気泡近傍の拡大図である. 計算領域は, 気泡を囲主 ように配置された 4 つのサブ領域と，その外側の 4つ のサブ領域から構成される. 各サブ領域は, 17 点の座 標から定義されており，17節点形状関数によりサブ領 域上の要素の節点座標が決定される. その際, 現象が 大きく変化する気泡近傍は細かく分割されている. 本 解析では，速度場には 9 節点 2 次要素が，圧力場には 4 節点 1 次要素がそれぞれ用いられている.

計算領域は，原点 $\mathrm{O}$ を中心する半径 $R$ の気泡表 面と, $z$ 軸加ら半径 $R_{\mathrm{w}}=1000 R_{0}$ の外側円筒壁面, $Z_{w}= \pm$ $\left(Z_{w 0}+\Delta H\right)$ の両平面で囲まれる領域である. $Z_{w 0}=1000 R_{0}$ とした.

\section{4. 支配方程式}

本解析で用いた支配方程式は, 連続式(10), 運動方 程式(11)，構成方程式(12)である.

$$
\nabla \cdot \boldsymbol{v}^{k}=0
$$

$$
\rho\left(\boldsymbol{v}^{k}-\hat{\boldsymbol{v}}^{k-1}\right) / \Delta t+\rho \hat{\boldsymbol{v}}^{k} \cdot \nabla \boldsymbol{v}^{k}=-\nabla p^{k}+\nabla \cdot \tau^{k}
$$

$$
\boldsymbol{\tau}^{k}=2 \eta \boldsymbol{S}^{k}=\eta\left\{\nabla \boldsymbol{v}^{k}+\left(\nabla \boldsymbol{v}^{k}\right)^{\mathrm{T}}\right\}
$$

ここに，kは時刻ステップであり， $\hat{\boldsymbol{v}}^{k-1}$ は時刻 $t$ におけ る速度であり， $\boldsymbol{v}^{k}$ は時刻 $t+\Delta t$ における速度である. 


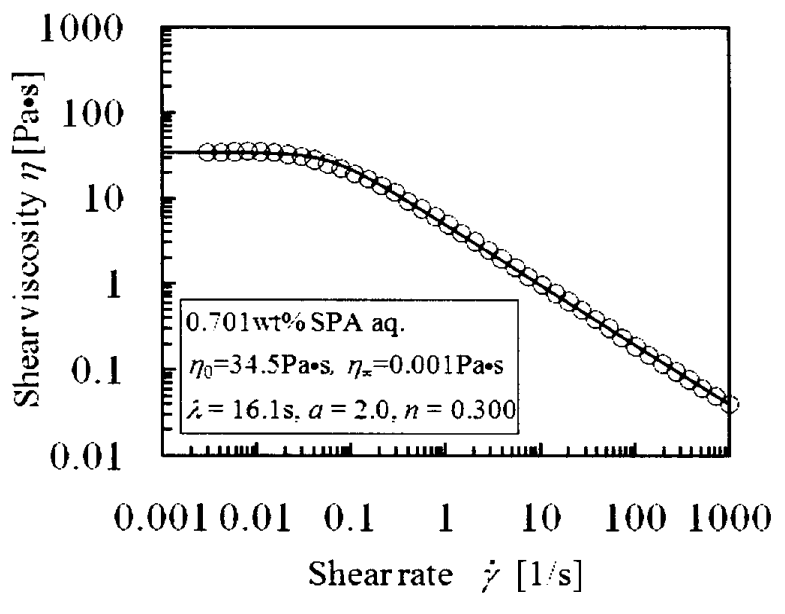

Fig.8 Dependence of viscosity on shear rate

記号 “へ”は，擬線形化のため，反復前段の值を用いて 既知項として取り扱うことを意味する. 時間刻み $\Delta t に$ は, 圧力振動の 1 周期 $(T=1 / f)$ の $1 / 100$ を用いた. $\rho$ は密 度, $p^{k}$ は压力, $\tau^{k}$ は偏差応力テンソル， $\nabla$ は勾配演算 子である.

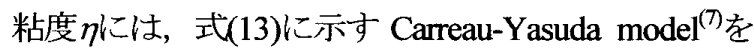
用いた. 式中の $\eta_{0}$ は零剪断粘度, $\eta_{\infty}$ は無限剪断粘度, $\lambda$ $a, n$ はモデルパラメータである. 図 8 中の○は, PTV 実験に用いられた $0.701 w t \% S P A$ aq. の剪断粘度デ ータであり，コーンプレートレオメータ (HAAKE 社 製 RS600)を用いて測定された結果である. 図中のパ ラメータは，最小 2 乗法により求められた.

$$
\eta=\eta_{\infty}+\left(\eta_{0}-\eta_{\infty}\right)\left[1+(\lambda \sqrt{2 \boldsymbol{S}: \boldsymbol{S}})^{a}\right]^{\frac{n-1}{a}}
$$

本解析の計算手順を以下に示す．また，Flow chart を図 9 に示す.

（1）積分領域の幾何形状を規定し，要素分割を行なう.

（2）気泡形状，速度の初期分布を設定する.

(3) 速度・压力場の拉大マトリックスを評洒する.

(4) デリクレ条件の設定後, マトリックスを解き, 速 度 $\boldsymbol{v}$, 圧力 $p$ を求める.

(5) 速度・圧力について，反復前段の値との相対誤差 が所定の収束判定条件 $(0.1 \%)$ を満足するまでLOOP 1 を計算する. 途中，新しく得られた解 $\boldsymbol{v}^{k}$ と反復前段 の值 $\hat{\boldsymbol{v}}^{k}$ を用い，緩和係数 $\omega$ を用い新しい既知項 $\hat{\boldsymbol{v}}^{k}$ を 求める.

（6）収束後，時間ステップを進め，気泡形状と上下境 界におけるサブ領域の形状を定義する 17 点の座標を 修正後, 要素再分割を行う。

(7) 所定の時刻になるまで LOOP 2 を計算し，結果を 出力する.

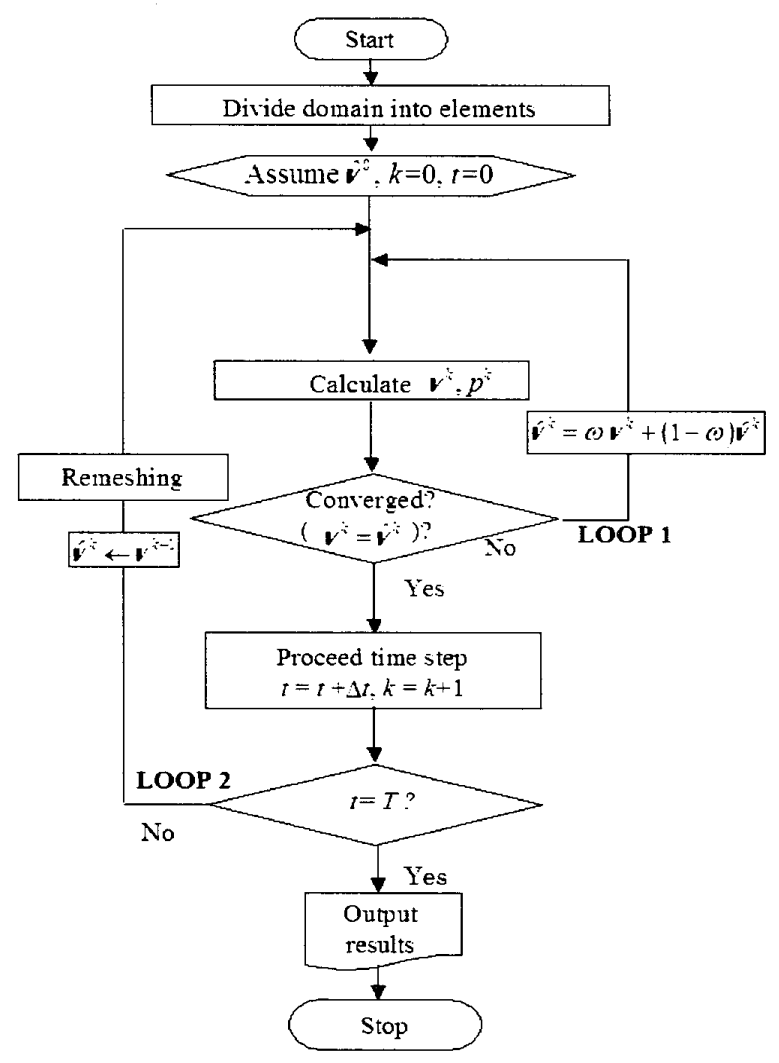

Fig.9 Flow chart

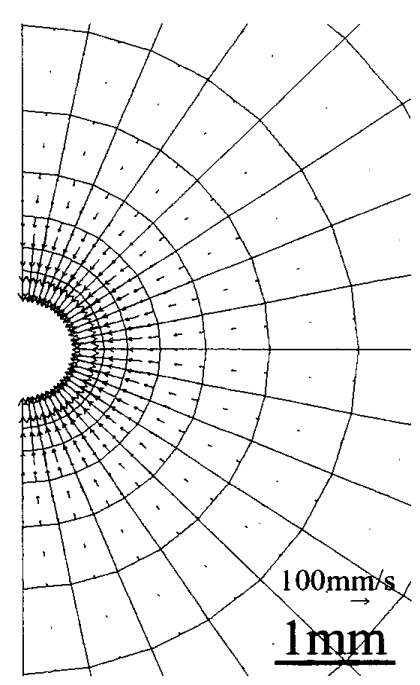

Fig.10 Velocity vectors around an oscillating bubble at $t=T / 2$

\section{5. 結 果}

図 8 の粘度特性を示す流体について, 図 5 に示す 1 周期相当の数值解析を行った. 気泡の収縮速度が最も 大きい時刻 $(=T / 2)$ における気泡近傍の速度ベクトルを 要素分割図とともに図 10 に示す.速度ベクトルは一様 に気泡中心に向かっており，その大きさは，気泡から 


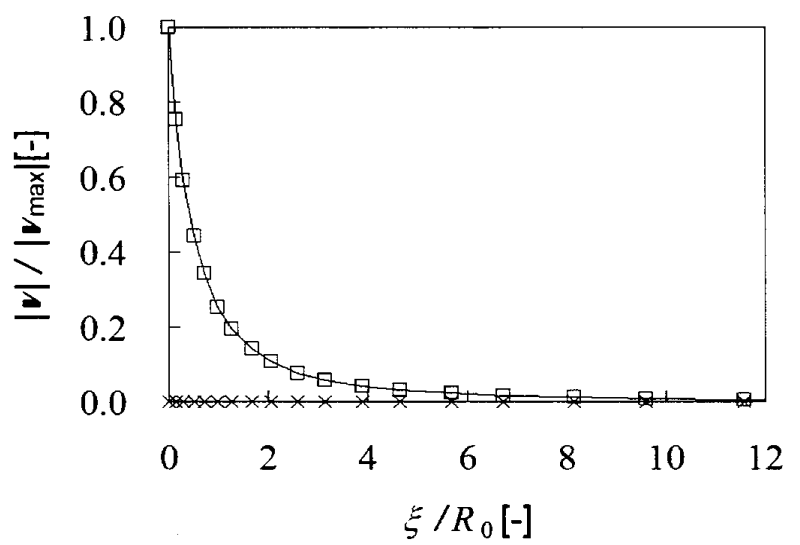

Fig.11 Effect of distance from bubble surface on velocity at $t=T / 4(\times)$ and $t=T / 2(\square)$

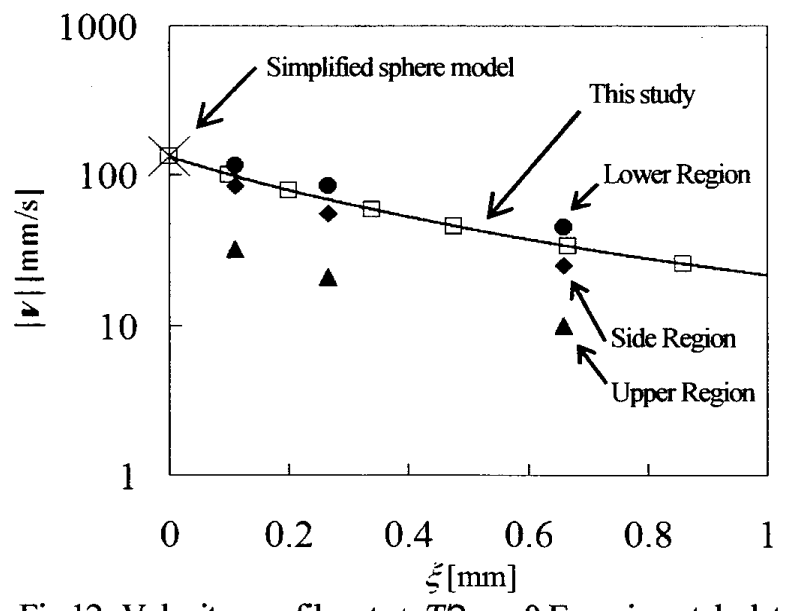

Fig.12 Velocity profile at $t=T / 2, z=0$ :Experimental data, predictions with simplified sphere model, and numerical results of FEM analysis

離れるにつれ，急激に減衰する様子がわかる。

図 11 は, $r$ 軸上の収縮速度を気泡表面における最大 速度で無次元化した無次元速度分布である. 口は時刻 $(t=T / 2)$ における速度節点值であり, $\times$ は時刻 $(t=T / 4)$ に おける速度節点値である. 横軸は，気泡表面からの 距離 $\xi$ 平均気泡半径で無次元化した無次元距離であ る.はじめにメに注目すると, 気泡は最も膨張した状 態であり，全ての領域に渡って，速度はほぼ 0 となっ た。一方，最も収縮速度が速い口に注目すると，気泡 表面近傍の速度は大きいが，その領域は非常に狭いこ とが分かる.わずか気泡半径の10 倍しか離れない領域 でも, 収縮速度はわずか $1 \%$ 未満であり，圧力振動場 では, 気泡の膨張収縮に伴う放射状の流れは気泡表面 の極近傍のみに存在することが分かった.

そこで, 気泡近傍の流れに注目し, PTV 実験から得 られた結果 ${ }^{(3)}$ と, 有限要素解析で得られた結果を比較 する. 数值解析では, PTV 実験に近い条件にするため, 周波数と, 最大気泡径と最小気泡径がそれぞれ一致す

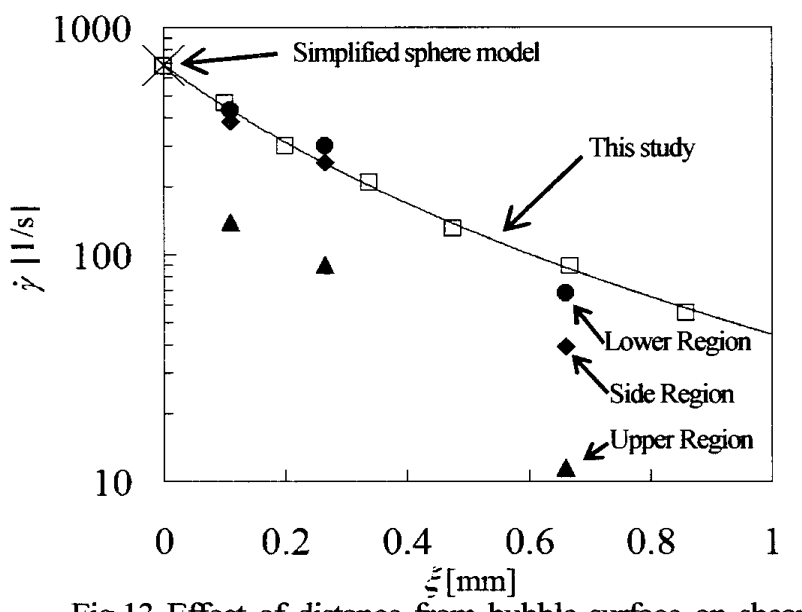

Fig.13 Effect of distance from bubble surface on shear velocity gradients: Experimental data, predictions with simplified sphere model, and numerical results of FEM analysis

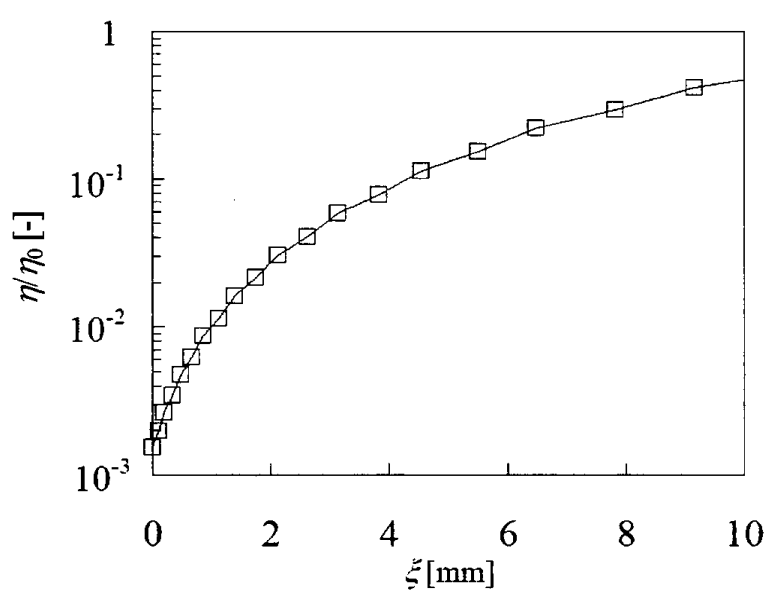

Fig.14 Effect of distance from the bubble surface on apparent viscosity at $t=T / 2$

るように設定されている. 図 12 は, 気泡表面から距離

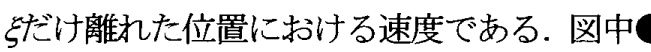

は, PTV 法で求められた実験結果であり，それぞれ気 泡下部，気泡側部，気泡上部の速度である. 口は，図 11 を有次元で示した結果であり, 補間線とともに示さ れている.PTV 実験結果に注目すると，気泡下部と気 泡側部の值が大きい.これは, 実験装置の構造により， セル内部の気泡は, セル下部のゴム膜を通じて圧力振 動が加えられ, 図 3 に示すように変形することが理由 と考えられる. 逆に, 気泡上部では, 流体がセル壁面 に囲まれており，速度は小さいことがわかる．

一方, 数值解析結果 $(\square)$ は, 気泡中心が固定されて おり，計算領域の上側，下側境界が上下対称に移動す ることから，実験装置の流れと完全には一致していな いが, 気泡下部(の)と気泡側部(け)との間にあり，気泡 表面から離れるにつれ両者は同じ傾向で速度が減哀す ることがわかった. さらに，気泡表面( $(=0)$ に注目する と, 真球モデル(1)で評価された結果 $(\times)$ が示されている. 
真球モデルの結果も, 数値解析結果と良好に一致した.

PTV 実験により式(3)から評価された剪断速度と， 数值解析により求められた剪断速度を図 13 に示した. 気泡の極近傍の領域では, PTV 実験で得られた気泡下 部(○)と気泡側部(・)の結果が良く一致しているもの の, 気泡表面から最も離れた PTV 実験結果は, 解析結 果より若干下回る結果が得られた.この領域では，卜 レーサーの移動量が小さく, 速度とその微分值に含ま れる測定誤差の影響と考えられる。一方，気泡表面 $(\xi=0) て ゙ の$ 真球モデルの結果は，解析結果と一致した. 両者は常に真球形状の気泡を取り扱っているためであ 万。

気泡表面( $\xi=0) て ゙ の$ 剪断速度は $674 \mathrm{~s}^{-1}$ であった.この 值は，瞬間的に得られる最大值ではあるが，図 8 の剪 断粘度曲線を参照すると，気泡表面では粘度が $\eta / \eta_{0}=$ $1.53 \times 10^{-3}$ まで下がることが考えられる. 同様に図 13 の剪断速度から評価した粘度分布を図 14 に示す.気泡 表面から約 $1 \mathrm{~mm}$ までの領域では，零剪断粘度の約 $1 \%$ 以下であり，瞬間的ではあるが，気泡は，粘度が低い 流体に囲まれることがわかった。この解析により，圧 力振動脱泡法における装置設計の指針を与えることが 示された.

今回行った数值解析は, 非ニュートン性は考慮され るものの，気泡中心座標が固定されており，常に真球 形状が保たれた解析である，また，実験に用いられた 試料流体は粘弾性流体であるが，今回の解析ではその 弾性の効果が検討されていない，高速で気泡が上昇す る場合，気泡はカスプ形状を呈することが報告されて おり (2)，気泡上昇に伴う Wake と圧力振動とが合わさ った複雑流れが気泡近傍に存在することが指摘されて いる. したがって，今後，気泡形状の変化が考慮され た非定常粘弾性流動解析の開発により，複雑流れの解 明が望まれる。

\section{6. 結 苝}

圧力振動場における気泡近傍の速度場と剪断速度 を非定常・非ニュートン有限要素解析により評価し， PTV 実験から得られた結果ならびに真球モデルで得 られた結果と比較を行った．速度場と局所剪断速度の どちらも結果は良好に一致し，筆者らが圧力振動場で 実験的に求めた速度場と局所剪断速度の評価法の妥当 性が示された。また，気泡の膨張収縮により，気泡近 傍に低粘度領域が瞬間的に存在することが示された。 これらの知見は，圧力振動脱泡の装置設計における指 針を与えることがわかった。

\section{文献}

(1) Iwata, S., Uchida, S., Ishida, K. and Mori, H., Pressure-Oscillatory Defoaming for Shear-thinning Fluids, Kagaku Kogaku Ronbunshu, Vol. 33, No.4 (2007), pp. 294-299.

(2) Iwata, S., Yamada, Y., Takashima, T. and Mori, H., Pressure-oscillating Defoaming for Viscoelastic Fluid, Journal of Non-Newtonian Fluid Mechanics, Vol. 151,No.1-3 (2008), pp. 30-37.

(3) Iwata, S., Yamada, Y., Komori, S. and Mori, H., Experimental Visualization of Local Flow of Shear-Thinning Fluid around a Small Bubble for Pressure Oscillating Defoaming, Kagaku Kogaku Ronbunshu, Vol. 34, No.4 (2008), pp. 417-423.

(4) Ohta, M., Kikuchi, D., Yoshida, Y. and Sussman, M., Direct Numerical Simulation of the Slow Formation Process of Single Bubbles in a Viscous Liquid, Journal of Chemical Engineering of Japan, Vol. 40,No.11 (2007), pp. 939-943.

(5) Dhole, S.D., Chhabra, R.P. and Eswaran, V., Drag of a Spherical Bubble Rising in Power Law Fluids at Intermediate Reynolds Numbers, Industrial and Engineering Chemistry Research, Vol. 46, (2007), pp. 939-946.

(6) Pillapakkam, S.B., Singh, P., Blackmore, D. and Aubry, N., Transient and Steady State of a Rising Bubble in a Viscoelastic Fluid, Journal of Fluid Mechanics, Vol. 589 (2007), pp. 215-252.

(7) Yasuda, K., Armstrong, R.C. and Cohen, R.E., Shear Flow Properties of Concentrated Solutions of Linear and Star Branched Polystyrenes, Rheologica Acta, Vol. 20, (1981), pp. 163-178. 